\title{
Introduction to a special Festschrift issue celebrating the microbiology of Cupriavidus metallidurans strain CH34
}

\author{
Simon Silver $\cdot$ Max Mergeay
}

Received: 28 May 2009/ Accepted: 11 June 2009/Published online: 24 June 2009

(C) Springer Science+Business Media B.V. 2009

Although this series of ten reports focuses on the microbiology of a single bacterium namely the betaproteobacterium Cupriavidus metallidurans $\mathrm{CH} 34$, this volume is of general interest for several reasons. Firstly, this unusual multiple toxic metal ion-resistant bacterium has been a model for how microbes handle such toxic metal (loids) from the time of its first isolation (Mergeay et al. 1978, 1985). Moreover, it continues to be a useful model, as seen in this series of reports as well as in any search of the literature, used for an expanding range of interests from metal response physiology (Nies et al. 1990, 1989; Nies 2000; Roux et al. 2001; Sendra et al. 2006) and basic molecular genetics (Lejeune et al. 1983), to genomics (the organism is unusual in having two chromosomes plus two large plasmids; Mergeay et al. 2003), microbial ecology (Vander Auwera, this series), to applications in environmental biotechnology (Diels, this series) and even in space research (Leys, this series).

As an introductory aside, but a necessary explanation here, strain $\mathrm{CH} 34$ is complicated in that it has had at least five official names, starting as a Pseudomonas strain (Mergeay et al. 1978), then Alcaligenes

\section{S. Silver}

Department of Microbiology and Immunology, University

of Illinois, Chicago, IL 60612, USA

e-mail: simon@uic.edu

M. Mergeay $(\bowtie)$

Unit Microbiology, SCK.CEN, Mol 2400, Belgium

e-mail: mmergeay@sckcen.be eutrophus (Lejeune et al. 1983), then Ralstonia eutropha, then Ralstonia sp., then Ralstonia metallidurans, to Wautersia metallidurans and finally (we hope) Cupriavidus metallidurans, including two changes in a single year (Vandamme and Coenye 2004), as the taxonomy of related bacteria evolved. Interested readers (if one wants useful and comprehensive literature) are advised to also search by "CH34" and not only by genus and species names. The letters $\mathrm{CH}$ refer to Christian Houba, at that time (in 1976), a student from the Université of Liège, who first isolated metal-resistant bacteria in a region in Belgium well known for its metallurgical industry historical past as well as for metal-accumulating plants.

The current reports are from a small Festschrift Symposium on work with strain $\mathrm{CH} 34$ that was held at the SCK.CEN (the Belgian Nuclear Research Centre of Mol) in April 2008. The science reported, included herein and much more that did not result in manuscripts, was a wonderful endorsement of the importance of this fascinating microbe, the benefits of a research program continuing over decades, and the fellowship and collegiality of the small international group of $\mathrm{CH} 34$ workers. We hope this continues.

\section{References}

Lejeune P, Mergeay M, Van Gijsegem F, Faelen M, Gerits J, Toussaint A (1983) Chromosome transfer and R-prime plasmid formation mediated by plasmid pULB113 
(RP4::mini-Mu) in Alcaligenes eutrophus $\mathrm{CH} 34$ and Pseudomonas fluorescens 6.2. J Bacteriol 155:1015-1026

Mergeay M, Houba C, Gerits J (1978) Extrachromosomal inheritance controlling resistance to cadmium, cobalt, copper and zinc ions: evidence from curing in a Pseudomonas. Arch Int Physiol Biochim 86:440-442

Mergeay M, Nies D, Schlegel HG, Gerits J, Charles P, Van Gijsegem F (1985) Alcaligenes eutrophus $\mathrm{CH} 34$ is a facultative chemolithotroph with plasmid-bound resistance to heavy metals. J Bacteriol 162:328-334

Mergeay M, Monchy S, Vallaeys T, Auquier V, Benotmane A, Bertin P, Taghavi S, Dunn J, van der Lelie D, Wattiez R (2003) Ralstonia metallidurans, a bacterium specifically adapted to toxic metals: towards a catalogue of metalresponsive genes. FEMS Microbiol Rev 27:385-410

Nies DH (2000) Heavy metal-resistant bacteria as extremophiles: molecular physiology and biotechnological use of Ralstonia sp. CH34. Extremophiles 4:77-82
Nies DH, Nies A, Chu L, Silver S (1989) Expression and nucleotide sequence of a plasmid-determined divalent cation efflux system from Alcaligenes eutrophus. Proc Natl Acad Sci USA 86:7351-7355

Nies A, Nies DH, Silver S (1990) Nucleotide sequence and expression of a plasmid-encoded chromate resistance determinant from Alcaligenes eutrophus. J Biol Chem 265:5648-5653

Roux M, Sarret G, Pignot-Paintrand I, Fontecave M, Coves J (2001) Mobilization of selenite by Ralstonia metallidurans $\mathrm{CH} 34$. Appl Environ Microbiol 67:769-773

Sendra V, Cannella D, Bersch B, Fieschi F, Ménage S, Lascoux D, Covès J (2006) CopH from Cupriavidus metallidurans $\mathrm{CH} 34$. A novel periplasmic copper-binding protein. Biochemistry 45:5557-5566

Vandamme P, Coenye T (2004) Taxonomy of the genus $\mathrm{Cu}$ priavidus: a tale of lost and found. Int J Syst Evol Microbiol 54:2285-2289 